\title{
香港、マカオにおける中国語母語話者を対象とした 片仮名先習に関する研究 \\ A Study of Teaching Katakana First for Chinese Language Speakers in Hong Kong and Macau
}

\section{郡司 拓也}

嶺南大学

\section{要旨}

本研究は一般に広く行われている平仮名先習とあまり一般的ではないと思われ る片仮名先習を比較調査し、学習者の片仮名への苦手意識に顕著な差が見られる かどうか明らかにすることを目的とする。

そこで本研究では「一般的な平仮名先習よりも、片仮名先習のほうが、片仮名 への苦手意識が低くなる」という仮説を検証した。

被験者は香港、マカオの大学で選択科目の日本語を履修する中国語母語話者の 学生で、実験群と統制群にわけ、実験群では片仮名を平仮名よりも先に導入する 方法で、統制群では平仮名を導入した後に片仮名を導入する一般的な方法で仮名 文字の導入を行い、その後再生テストとアンケート調查を実施し、分析した。

今回の調査結果から、まず学習者は先に学んだ仮名文字を易しいと感じる傾向 が見られることが明らかとなった。

また片仮名の音から文字の形を認識すると言う点に関して、片仮名先習のほう が平仮名先習より苦手意識を感じにくいということが明らかとなった。

さらに再生テストの結果からは片仮名先習のほうが平仮名先習よりも平仮名、 片仮名ともに平均点が高く、平仮名先習に比べ、平仮名の定着においても特に支 障は見られず、むしろ良い結果となった。

\section{キーワード：}

中国語母語話者、片仮名先習、文字教育、苦手意識 


\section{香港、マカオにおける中国語母語話者を対象とした 片仮名先習に関する研究}

郡司 拓也

嶺南大学

\section{1.はじめに}

河原崎（1989）も述べているように、日本語教育において、片仮名はあまり重 視されていない。これは片仮名が主に外来語の表記や擬声語の表記などに限られ ており、日本語教育の最初の段階においてはそれほど使用される場面が多くない ことに起因しているとされてきた。

そのため、多くの日本語教育機関において、平仮名がまず先に丁寧に導入され、 片仮名はその後に付随的に導入されてきたのであろう。

しかし、大学や日本語学校などで日本語を毎日のように学んでいる学習者はま だしも、香港やマカオの大学で選択科目として日本語を学んでいる学習者の場合、 時間的制約から仮名文字の指導になかなか時間を費やすのが困難なことも多く、 50 音図を利用し、仮名文字の形や音、書き順を紹介するだけという導入法が一般 的なようだ。また一般的に週に 3 時間程度しか授業がないため、日本語に触れる 機会も少なく、片仮名を学んでから 2 年、3 年経ってもまだ片仮名がなかなか容易 に読み書きできないというケースも少なくない。

近年、中山（2007）の調查にあるように外来語を中心に片仮名語が日本語の語 彙に占める割合は以前よりもかなり高くなっており、片仮名教育の見直しをす心゙ きだという声も増えつつあるようである。

しかし、片仮名教育に関する論文の多くは片仮名語の教育に関するものがほと んどであり、片仮名の文字教育に関するものはあまり見られない。

仮名文字の導入法に関しては中山（2006）の調査結果にあるように平仮名を先 に導入し、その後片仮名を導入するというのが一般的であるようだが、片仮名を 先習することにより、学習者からしばしば耳にする片仮名が苦手だと言う問題を 少しでも改善できるのではないかと考えたのが、本研究の出発点である。

\section{2. 先行研究などから見る片仮名教育の状況}

\section{1 学習者の片仮名への苦手意識}

中山（2006）の国内の日本語教育機関に在籍している 479 名の日本語学習者を 対象に行った調查の中で、片仮名と平仮名を読むことに対する意識調査の項目が ある。その結果、片仮名に対して難しくないと回答したのは $27.3 \% に$ 過ぎなかった 


\section{香港、マカオにおける中国語母語話者を対象とした \\ 片仮名先習に関する研究}

のに対し、平仮名では $78.7 \%$ が難しくないと回答しており、対照的な結果が出て いる。この調査では母語や学習歴などが様々であるので、その要因を分析するこ とは難しい。しかし調査対象者の $59.5 \%$ がすでに 1 年以上日本で日本語を学習し ており、35.5\%は日本語能力試験の N1 受験経験者であるということを考えると、 日本で生活し、日本語を学んでいる中上級レベルの日本語学習者であっても片仮 名に対して難しいと感じている学習者が多いということは驚きを隠せない。教科 書だけでなく、教室外でも片仮名語を含む多くの日本語の語彙に触れる機会の多 い日本在住の学習者でさえこれだけの苦手意識を持っているのだから、日本国外 で教科書以外の日本語に触れる機会のあまり多くない学習者が片仮名に対して苦 手意識を持つであろうことは容易に想像がつく。

\section{表 1 片仮名、平仮名を読むことに対する学習者の意識}

Q15(1) カタカナを読むことについて、どのように感じていますか。

Q15(2)それでは、ひらがなを読むことについて、どのように感じていますか。

\begin{tabular}{|c|c|c|c|c|c|}
\hline & とても難しい & 難しい & 少し難しい & 難しくない & 無回答 \\
\hline カタカナ & $27(5.6 \%)$ & $109(22.8 \%)$ & $209(43.6 \%)$ & $131(27.3 \%)$ & $3(0.6 \%)$ \\
\hline ひらがな & $3(0.6 \%)$ & $10(2.1 \%)$ & $83(17.3 \%)$ & $377(78.7 \%)$ & $6(0.1 \%)$ \\
\hline
\end{tabular}

中山（2006）

\section{2 教科書に占める片仮名語の占める割合}

それでは特に日本国外で日本語を学習する場合によりどころとなる教科書にお いて、片仮名語はどのぐらいの割合を占めるのだろうか。香港、マカオでの初級 レベルの学習者の使用を想定し、国際交流基金日本語国際センター図書館が所蔵 する初級レベルの日本語総合教科書の中で、香港、マカオの高等教育機関での使 用が確認されているもの、また香港で出版、または販売が確認されている 12 冊を 対象に、片仮名使用語彙数の割合を調査した。その結果、異なり語数でその平均 使用率はわずか $8.1 \%$ であことが明らかとなった。 
表 2 香港、マカオの日本語初級教科書に占める片仮名語の使用割合

\begin{tabular}{|c|c|c|c|c|}
\hline No. & 書名 & 総語数（異なり語数） & 片仮名使用語数 & 割合 \\
\hline 1 & ジェイ・ブリッジ 1 & 880 & 116 & $13.2 \%$ \\
\hline 2 & ジェイ・ブリッジ 2 & 883 & 66 & $7.5 \%$ \\
\hline 3 & 日本語初歩 & 1702 & 101 & $5.9 \%$ \\
\hline 4 & みんなの日本語初級 1 & 1043 & 42 & $4.0 \%$ \\
\hline 5 & みんなの日本語初級 2 & 1075 & 108 & $10.0 \%$ \\
\hline 6 & 新文化初級 1,2 & 1908 & 269 & $14.1 \%$ \\
\hline 7 & 大地 1,2 & 2180 & 302 & $13.9 \%$ \\
\hline 8 & $\begin{array}{c}\text { 日本語 } 1,2 \\
\text { (香港中文大学編) }\end{array}$ & 1735 & 130 & $7.5 \%$ \\
\hline 9 & 日語基礎講座 1 & 255 & 6 & $2.4 \%$ \\
\hline 10 & 日語基礎講座 2 & 350 & 22 & $6.3 \%$ \\
\hline 11 & 日語基礎講座 3 & 264 & 17 & $6.4 \%$ \\
\hline 12 & 日語基礎講座 4 & 325 & 19 & $5.8 \%$ \\
\hline
\end{tabular}

ちなみに中山（2007）の資料に収録されていた日本語学習教材の総語彙数に占 める片仮名語数の割合は総合教科書だけでなく、文字学習教材なども含み、異な り語数でなく、延べ語数であるという違いはあるものの、初級 $11.9 \%$ 、初中級 $12.1 \%$ 、中級 $12 \%$ 、上級 $6.3 \%$ となっており、初級において約 $10 \%$ という点では本 稿の調查結果とほぼ変わらないことが明らかとなった。中上級レベルでもその割 合は大きく変わらないが、一般に中上級では教科書以外の書籍や新聞などの生教 材などに触れる機会も増えると思われるので、片仮名語に触れる機会も実際は初 級よりは多いかもしれない。しかし、初級レベルの場合、いわゆる基本語彙や文 型の習得が中心となるので、書籍や新聞などの教科書以外の生教材に触れる機会 も少なく、教師や教育機関が特に意識しない限り、片仮名に触れる機会はかなり 少なくなることは否めない。 


\section{香港、マカオにおける中国語母語話者を対象とした \\ 片仮名先習に関する研究}

\section{3 片仮名教育への教師や教育機関の意識}

それでは教師や教育機関は片仮名教育に対してどのように取り組んできたのだ ろうか。河原崎（1989）は「日本語教育の中でも、片仮名ほど粗末に扱われてい るものはないだろう。まず教材がない。研究にいたっては数えるぐらいで、その 教授法はいまだ未開発である。」とし、「外国人に対する片仮名教育に関して言 えば、昭和三○年代から、進歩が見られないといっても過言ではない。」とまで 述べている。また片仮名の文字そのものの教授法に関して、「片仮名は日本語教 育の入門期に指導されるが、その後は系統立って指導されない。」と述心、また 「仮名の教科書も少なく、平仮名はともかく、片仮名になると、五十音図ですまし てしまう機関が多い。」と平仮名に比べ、片仮名の教育には力が入れられていな いのではないかという指摘をしている。

河原崎の指摘から約 20 年経ったにもかかわらず、中山（2007）は状況がその指 摘当時とあまり変わっていないと述心゙、教師や教育機関への調查結果から、片仮 名に関して平仮名と同程度の読み書き能力をつけることを目指すと回答した機関 は片仮名文字教育を行っている 48 機関中 28 機関と 6 割弱に過ぎず、十分定着し ているという回答はわずか 2 機関で、かなり定着しているという21機関を合わせ ても、5 割に満たないというデータを示した上で、「日本社会において日本語を学 習し、日本語を用いて生活するにあたっては、カタカナは避けては通れないもの であるにもかかわらず、日本語教育においては、文字も語彙もその存在に見合う だけの教育がなされていない。だからこそカタカナ教育の確立が必要なのであ る。」と主張している。

\section{4 先行研究における片仮名教育の改善策}

中山（2007）ではそういった状況の打開策として、片仮名の導入時期を入門期 から初級期にずらすという方法を提案し、「漢字学習にある程度慣れてきたとこ ろで、一日に数語のカタカナ語を入れながら、そこに使われている文字を入れて いく。初級が終わるころには、文字全てとある程度のカタカナ語が定着している、

という方法である。」とその方法について述べている。そして、その実施のため には「カタカナ語を吟味して選定した教材」が必要であり、その導入語彙につい て、「語彙調査の結果から、まず基本カタカナ語を選定し、その基本カタカナ語 の中から選ぶのが望ましい。」と主張している。

ここで注目すべき点は片仮名教育の重要性を指摘しているが、その中心は片仮 名の語彙であり、片仮名の文字そのものではないというところである。これは中 
山（2007）に収録されている他の論文でも同様であり、片仮名や片仮名教育に関 する先行研究では、そのほとんどが外来語の表記の問題とその習得の困難がテー マとなっており、片仮名の文字教育に関するものは、わずかに連想法を使ったも のなどを除くとほとんど見られない。これは郡司（2014）でも指摘しているよう に片仮名だけでなく、平仮名に関しても同様であるが、中でも片仮名は平仮名に 比べてより少ない。

平仮名も片仮名も漢字から派生した表音文字という点で共通しており、文字数 もまた同じである。にもかかわらず、表 1 のように片仮名と平仮名とで苦手意識 に非常に大きな差が出てくるのは何故だろうか。もちろん平仮名に比べ、表 2 の ように教科書に提示される片仮名で表記される語彙が少なく、目にする機会が少 ないということが考えられるが、先程の中山（2007）の調査結果にもあるように 導入段階での教育機関や教師側の片仮名の扱いの軽さも片仮名習得への苦手意識 を生んでいる要因となっているのではないだろうか。そしてそのことがもし学習 者に「片仮名は平仮名のついでに覚えさせられるあまり重要でない文字」という 認識を持たせてしまっているとしたら、教育機関や教師側が片仮名への扱いを変 えることで、学習者の片仮名への苦手意識を減らすことができるかもしれない。 つまり片仮名は平仮名のついでに学ぶものではないという意識付けをするという 改善策である。

\section{3. 研究の目的と方法}

本研究は平仮名と片仮名の導入順序について、一般に広く行われている平仮名 先習とあまり一般的ではないと言われている片仮名先習の 2 つの仮名文字導入法 を比較調査し、学習者の片仮名に対する苦手意識に顕著な差が見られるかどうか を明らかにすることを目的とする。

そこで「一般的な平仮名先習よりも、片仮名先習のほうが、片仮名への苦手意 識が低くなる」という仮説を以下の手順により検証していく。

\section{1 調査対象と調査の手順}

被験者は香港、マカオの大学で選択科目として日本語を履修する中国語母語話 者の学生である。母語による影響を排除するため、それ以外の母語話者は調査対 象から外した。そのうち、既習者を除いた日本語未習者の 254 名を主な調査対象 とした。この 254 名のうち、176 名を実験群、78 名を統制群 ${ }^{1}$ して扱った。

178 名の統制群の調查対象者は郡司（2014）における字源法を用いた仮名文字導入法の調査 対象とした中国語母語話者であり、その際の調査データを今回の実験群との比較に利用して いる。 


\section{香港、マカオにおける中国語母語話者を対象とした \\ 片仮名先習に関する研究}

実験群では片仮名を平仮名よりも先に導入する順序で、統制群では平仮名を 導入した後に片仮名を導入する一般的な順序で仮名文字の導入を行い、その後 再生テストとアンケート調査を実施し、分析した2。

調査にあたっては両群の等質性を担保するために、仮名文字の導入順序以外の 教材や導入方法、導入に費やす時間などに違いが出ないよう細心の注意を払った。

なお既に数か月から 1 年程度日本語を学習した経験のある既習者 99 名（実験群 68 名、統制群 31 名）に関しては上記の調査対象外としているが、従来型の五十音 図を基に仮名文字を、平仮名、片仮名の順序で習得した学習者であることから、 参考として、未習者である被験者と同様の再生テストとアンケート調査を実施し、 その結果の比較を一部調査で行った。具体的な調査の手順は以下のとおりである。

まず 1 週目に実験群、統制群ともに日本語の音についてローマ字を使用して 導入、練習した。次に 2 週目に授業の約 1 時間を使って、実験群では片仮名を、 そして統制群では平仮名を導入した。そして 3 週目にそれぞれ、片仮名、平仮名 の再生テストとアンケートを実施した後、実験群では平仮名、統制群では片仮名 を約 1 時間かけて導入し、最後に 4 週目にそれぞれ平仮名、片仮名について 3 週 目と同様の再生テストとアンケートを実施した。

仮名文字の導入方法に関しては実験群、統制群ともに郡司（2014）と同様、 富山大学留学生センターのオンライン教材を使用し、字源となる漢字を確認し、 その中国語音から仮名文字の音を類推するという連想法の手法を用いた。授業後 はテスト前に練習帳への書き取りを宿題とし、またオンライン教材で自習する よう促した。教室外での自習などについてはとくに制限しなかった。3

\section{2 再生テストとアンケート調查の内容}

再生テストは平仮名、片仮名の文字を見て、その音を再生できるかどうかを調 査する目的で行った。テスト内容は郡司（2014）と同じものであり、平仮名、片 仮名のそれぞれ 46 文字の直音から 30 文字ずつを抽出したものとなっており、解 答は 1 週目の授業で導入したローマ字表記を用いて行う形式を採用した。46文字 のすべてを出題しなかったのは、通常の授業内で行った調査であることから、

2 調査対象者を含む全受講生にはあらかじめ再生テストの結果などは成績に関係はなく、調査 目的にのみ使用寸る旨を説明してあり、同意を得た上で通常授業の中で調查を行った。

${ }^{3}$ Matsunaga（2003）が述べているように、テストを後日行う場合、被験者が実験授業外で自習 した影響がテストに反映される可能性が考えられるが、本研究では通常の授業の一環で調查 を実施することから、授業外での復習を禁止するようなことはできない。 
授業進度に影響が出ないように、テストの実施時間を少しでも短縮したかったと いう事情と、すべての文字を出題すると適当にすべての回答欄を埋めようとする 被験者が出てくるのではないかという懸念があったことによる。

またテストと同時にアンケートを実施した。平仮名、片仮名それぞれについて、 文字の音を覚えることと文字の形を覚えることに対する苦手意識について、「と ても難しい」、「難しい」、「あまり難しくない」、「簡単」という４段階で回 答をするという形式で行った。

\section{4. 分析結果と考察}

\section{1 再生テストの結果とその分析}

まず再生テストの結果について分析する。表 3 にあるとおり、平仮名、片仮名 ともに片仮名先習のほうが平均点が高いという結果となった。平仮名先習のほう で平仮名の平均点が片仮名先習に比べ、3.94 点も低かった点が注目されるが、こ の点については、文字の学習方法やテスト形式に慣れたため、最初に学んだ平仮 名よりも、次に学んだ片仮名のほうが平均点が高くなったのかもしれない。また いずれの方法でも片仮名の平均点が高い結果となったことから考えると、文字自 体の習得に関しては平仮名より、片仮名の方が少なくとも短期記憶としては容易 であるという可能性が考えられる。

なお既習者の結果に関しては平仮名も片仮名も平均点は 28 点台と高く、差は非 常に小さかった。

表 3.テスト結果

\begin{tabular}{|c|c|c|}
\hline 30 点満点 & 平仮名 & 片仮名 \\
\hline 平仮名先習 & 21.87 & 25.77 \\
\hline 片仮名先習 & 25.81 & 26.51 \\
\hline 既習者 (参考) & 28.56 & 28.37 \\
\hline
\end{tabular}

\section{2 アンケート調查の結果とその分析}

次に再生テストと同時に行ったアンケート調查について分析する。アンケート 調查は 2 種類あり、平仮名と片仮名について、全体的に見てどちらが易しいと思 うかという質問と平仮名と片仮名の音と形に関して、それぞれどんな点が難しい、 あるいは易しいと感じるのかという質問を行った。 


\section{2.1 平仮名と片仮名に対する全体的な印象}

まず平仮名と片仮名に対する全体的な印象に関する調查では、「一般的な平仮 名先習よりも、片仮名先習のほうが、片仮名への苦手意識が低くなる」という仮 説を、「片仮名を先習した集団では平仮名より片仮名のほうが易しいという印象 を持つ」と置き換え、これを立証することとした。

表 4. 平仮名と片仮名に対する全体的な印象

\begin{tabular}{|c|c|c|c|}
\hline & 平仮名易しい & 片仮名易しい & 総計 \\
\hline 片仮名先習 & 42 & 110 & 152 \\
\hline 平仮名先習 & 41 & 25 & 66 \\
\hline 総計 & 83 & 135 & 218 \\
\hline
\end{tabular}

検定統計量 $\mathrm{T}=23.22 * * *$

*は $\mathrm{P}<.1$ 、**は $\mathrm{P}<.05 、 * * *$ は $\mathrm{P}<.01$ を表す

アンケートでは仮名文字学習後の印象として、「平仮名のほうが易しい」、「片 仮名のほうが易しい」、「どちらも易しい」という 3 つの選択肢から自分の感覚 に最も近いものを選んでもらった。そしてその中から、「平仮名のほうが易しい」 と「片仮名のほうが易しい」という回答を抽出し、2×2 のクロス表に再編したう えで、クロス表分析を行い、カイ二乗検定を行い、仮説を検証した。

その結果、 $1 \%$ 水準で有意差があることが認められた。つまり片仮名、平仮名と もに、先に導入された仮名文字のほうが易しいと感じるということが明らかとな った。

興味深いのは、先程の表 3 の再生テストの結果で、片仮名先習を行った実験群 では、平仮名と片仮名の再生テストの平均点の差がほとんどなかったが、平仮名 先習を行った統制群では再生テストの平均点では平仮名より片仮名のほうが高か ったにもかかわらず、平仮名のほうが易しいという回答が回答全体の半数以上 $(52.6 \%)$ を占めた点である。

なお、従来型の 50 音図を元に仮名文字を平仮名先習で学んだ既習者との比較を 行ってみたところ、今回の調査の統制群と同様に平仮名のほうが易しいという回 答が多く、その割合はより高かった4。このことから50 音図を使うか、連想法を 使うかという導入方法の違いに関わらず、先に導入された仮名文字のほうが易し いと感じると言えそうである。

42.2 で述べたように、教科書の中では片仮名より平仮名に触れる機会のほうが非常に多いの で、そうした学習経験の影響が表れているのかもしれない。 
表 5. 平仮名と片仮名に対する全体的な印象（既習者との比較）

\begin{tabular}{|c|c|c|c|}
\hline & 平仮名易しい & 片仮名易しい & 総計 \\
\hline 片仮名先習 & $42(27.6 \%)$ & $110(72.4 \%)$ & $152(100 \%)$ \\
\hline 平仮名先習 & $41(62.1 \%)$ & $25(37.9 \%)$ & $66(100 \%)$ \\
\hline 既習者 & $63(82.9 \%)$ & $13(17.1 \%)$ & $76(100 \%)$ \\
\hline
\end{tabular}

\subsection{2 平仮名と片仮名のそれぞれの音と形に対する個々の苦手意識の違い}

次に平仮名と片仮名のそれぞれの音と形に対する苦手意識に関して行ったアン ケート調查の結果についてクロス表分析を行った。片仮名と平仮名のそれぞれ音 と形に対する苦手意識について、片仮名先習と平仮名先習の導入順序の違いによ って顕著な差異が見られるかどうか、カイ二乗乗検定を行って検証した。

しかし「とても難しい」「難しい」「あまり難しくない」「簡単」という4 段 階での結果では值が０となり、独立性の検定を行うことができない項目があった ため、「とても難しい」と「難しい」を合わせて「難しい」に、「あまり難しく ない」と「簡単」を合わせて「易しい」にまとめて 2 段階とし、 $2 \times 2$ のクロス表 に再編した。そのうえで、どの項目に関して強い苦手意識が見られるかという分 析を行った。

その結果、片仮名の形に関して、片仮名先習と平仮名先習の間に 5\%水準で有意 差があることが明らかになった。

このことから片仮名の形状を学ぶという点に関し、片仮名先習は一般的に行わ れている平仮名先習に比べて、学習者の苦手意識を軽減させるある一定の効果が あると考えられる。

表 6. 平仮名の形

\begin{tabular}{|c|c|c|c|}
\hline & 難しい & 易しい & 総計 \\
\hline 片仮名先習 & 96 & 80 & 176 \\
\hline 平仮名先習 & 47 & 30 & 77 \\
\hline 総計 & 143 & 110 & 253 \\
\hline
\end{tabular}

検定統計量 $\mathrm{T}=0.92$

*はP<.1、**はP $\mathrm{P}<.05 、 * * *$ は $\mathrm{P}<.01$ を表す

表 8. 片仮名の形

\begin{tabular}{|c|c|c|c|}
\hline & 難しい & 易しい & 総計 \\
\hline 片仮名先習 & 73 & 103 & 176 \\
\hline 平仮名先習 & 43 & 35 & 78 \\
\hline 総計 & 116 & 138 & 254 \\
\hline
\end{tabular}

検定統計量 $\mathrm{T}=4.06 * *$

$*$ は $\mathrm{P}<.1 、 * *$ 、 $\mathrm{P}<.05 、 * * *$ は $\mathrm{P}<.01$ を表す
表 7. 平仮名の音

\begin{tabular}{|c|c|c|c|}
\hline & 難しい & 易しい & 総計 \\
\hline 片仮名先習 & 66 & 110 & 176 \\
\hline 平仮名先習 & 35 & 42 & 77 \\
\hline 総計 & 101 & 152 & 253 \\
\hline
\end{tabular}

検定統計量 $\mathrm{T}=141$

*は $\mathrm{P}<.1 、 * *$ 、 $\mathrm{P}<.05 、 * * *$ * $\mathrm{P}<.01$ を表す

表 9.片仮名の音

\begin{tabular}{|c|c|c|c|}
\hline & 難しい & 易しい & 総計 \\
\hline 片仮名先習 & 59 & 117 & 176 \\
\hline 平仮名先習 & 31 & 46 & 77 \\
\hline 総計 & 90 & 163 & 253 \\
\hline
\end{tabular}

検定統計量 $\mathrm{T}=1.06$

$*$ は $\mathrm{P}<.1 、 * *$ 、 $\mathrm{P}<.05 、 * * *$ は $\mathrm{P}<.01$ を表す 


\section{香港、マカオにおける中国語母語話者を対象とした \\ 片仮名先習に関する研究}

\section{5. まとめ}

今回の調査結果から、まず学習者は先に学んだ仮名文字を易しいと感じる傾向 が見られることが明らかとなった。これは表 1 の中山（2006）の調查結果とも矛 盾しない。

また片仮名の音から文字の形を認識すると言う点に関して、片仮名先習のほう が平仮名先習より苦手意識を感じにくいということが明らかとなった。ただし、 この仮名文字の形や音に対する苦手意識に関する調査に関しては、仮名文字の字 源となる漢字を利用した教授法を利用して調査を行っているため、従来型の 50 音 図を利用した仮名文字教授法など、その他の方法でも同様の結果が出るのかどう かは明らかとなっていない。この点は今後の課題としたい。

さらに再生テストの結果からは片仮名先習のほうが平仮名先習よりも平仮名、 片仮名ともに平均点が高く、平仮名先習に比べ、平仮名の定着においても特に支 障は見られず、むしろ良い結果となった 5 。

この調査結果自体はあくまで短期記憶に関する結果に過ぎないが、その後の授 業においても、片仮名先習を行ったことで、平仮名を使用した語彙や文型の習得 などの際に、平仮名先習と比較して、特に学習者が困難を感じているような様子 は見られなかった。

これは漢字と平仮名の語彙は教科書の $90 \%$ 近くを占めており、語彙や文法な どを学ぶ中で、平仮名を見て漢字の語彙を発音をしたり、平仮名を読み書きする 機会が非常に多いことに起因するのではないかと思われるが、実際に約 3 ケ月の コース終了時に平仮名の読み書きに関してはほとんどの学生が十分に習得できて いた。

それに対して、片仮名に関してはやはり時間が経つと、教科書で提示される機 会も平仮名と比較すると少ないためか、平仮名に比べると、読み書きが十分でき ているとはいえない学生も多少目につくこともあった。この点に関しては教育機 関や教師側が意識して、そのコース、学習者に適切で、重要と思われる片仮名語 彙を継続して、提示し、触れさせることで、短期記憶から長期記憶へと繋げてい けるのではないかと思われる。その際、先行研究にあるような片仮名語彙に関す る研究が参考になるだろう。

片仮名先習により、片仮名の文字への苦手意識が減少することで、その次の段 階の片仮名の語彙の教育においても学習効果が上がることを期待したい。

5 今回の再生テストでは仮名文字の「読み」の定着度しか調べていないので、「書き」の定着 度に関しては明らかになっていない。 


\section{参考文献}

河原崎幹夫(1989) 「片仮名の指導法」加藤彰彦(編)『講座日本語と日本語教育 9 日本語の文 字・表記（下）』明治書院，245-289

郡司拓也（2014）「香港、マカオの高等教育における中国語母語話者を対象とした仮名文字の 教授法の研究一その字源を利用して一」第 9 回国際日本語教育・日本研究シンポジウム論文 集編集会編『日本語教育と日本研究における双方向性アプローチの実践と可能性』ココ出版, 229-241

富山大学留学生センター 日本語学習支援サイトRAICHO 「日本語自己学習」

<http://raicho.ier.u-toyama.ac.jp/raicho-cgi-bin/quiz/quiz.cgi?mode=list_tests> (2015 年 10 月 31 日)

中山恵利子（2006）『日本語教育現場におけるカタカナ教育の実態調査』（平成 17 年度〜18 年度科学研究費補助金基盤研究 (C) 課題番号 17520358 平成 17 年度研究成果報告書 中山恵利子（2007）『カタカナ教育の基礎的研究一日本語教育における分野の確立を目指して一』

(平成 17 年度 18 年度科学研究費補助金基盤研究 (C) 課題番号 17520358 研究成果報告書 Matsunaga, Sachiko. (2003) Effects of Mnemonics on Immediate and Delayed Recalls of Hiragana by Learners of Japanese as a Foreign Language, “世界の日本語教育” 13, 19-40 